\title{
金属の腐食の基礎概念と最近の研究の進歩
}

\author{
原信 義* \\ 東北大学 进 980-8577 仙台市青葉区片平 2-1-1 \\ （2019 年 10 月 15 日受付；2019 年 12 月 4 日掲載決定）
}

\section{Fundamentals and Recent Developments in Understanding of Metal Corrosion}

\author{
Nobuyoshi HARA*
}

Tohoku University, 2-1-1, Katahira, Aoba-ku, Sendai 980-8577

(Received October 15, 2019 ; Accepted December 4, 2019)

\begin{abstract}
The fundamentals for understanding metal corrosion in aqueous solutions are first explained in terms of thermodynamics and kinetics of electrochemical corrosion reactions, illustrating the validity of a local cell model for the uniform corrosion behavior of iron and stainless steels. Then, the passivation process of stainless steels and the important properties of their passive films are described. Finally, recent studies on the pit initiation mechanism at sulfide inclusions of stainless steels are introduced, which provides a valuable information to develop a next-generation green stainless steel.
\end{abstract}

KEYWORDS : metal corrosion, electrochemical process, stainless steel, passive film, pitting

\section{1.は じめ に}

腐食とは，材料がそれを取り巻く環境との間に生ずる 不可逆反応であり, 通常は材料そのものの劣化あるいは 性質の変化を伴う。腐食環境が水溶液である場合の腐食 を湿食あるいは水溶液腐食, 気体である場合の腐食を乾 食と呼ぶ。乾食に溶融塩や溶融金属による腐食を加えて 高温腐食と総称することもある。金属材料の腐食は中性 の金属原子から電子が引き抜かれて正の原子価が増加す る酸化反応であるから, 反応式自体は単純なことが多い が, 実際の腐食現象は複雑化することがある。材料側に も環境側にも腐食に影響する要因は多数存在するからで ある。したがって, 実際の腐食問題の解決には幅広い知 識が必要とされるが, その基本は腐食現象を電気化学的 に捉らえることである。

本稿では水溶液腐食を理解するために必要な電気化学 的理論を概説したのち, 局部腐食に関する最近の研究の 進歩を紹介する。腐食の基礎概念に関しては以前に「真 空」誌上で詳しく解説しているので1), ここでは特に重
要な事項に絞り，また対象材料を鉄とステンレス鋼に限 定して説明する。

\section{2. 水溶液腐食の電気化学}

\section{1 腐食現象の分類}

代表的な水溶液腐食の分類を Fig. 1 に模式的に示す。 腐食形態と機構に基づいて, 均一腐食（Fig. 1 (a), 全 面腐食とも呼ばれる）と局部腐食（Fig. 1（b）～(e)）と に大別され，後者には孔食（Fig. 1 （b)），すき間腐食 （Fig. 1 (c)）, 粒界腐食（Fig. 1 (d)）, および応力腐食 割れ（Fig. 1 (e)）などがある。大気腐食も水溶液腐食 の一種である。ここでは, もっとも分かりやすい均一腐 食について電気化学的な考え方を述べる。

\subsection{Nernst の式と Butler-Volmer の式}

腐食は電気化学的プロセスであるから, 電極反応の熱 力学と反応速度論を知っておく必要がある。電極反応の 平衡電位を熱力学的に導く Nernst の式と, 電極反応の 速度を表す Butler-Volmer の式が重要である。ここでは 次式のような一般化された電極反応を考える。

$$
x \mathrm{~A}+y \mathrm{~B}+z \mathrm{e}^{-}=m \mathrm{C}+n \mathrm{D}
$$




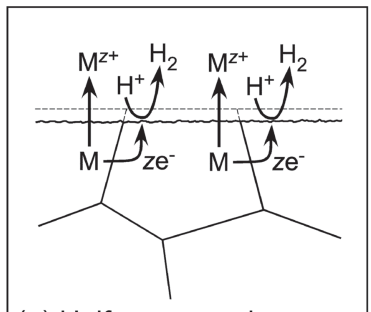

(a) Uniform corrosion

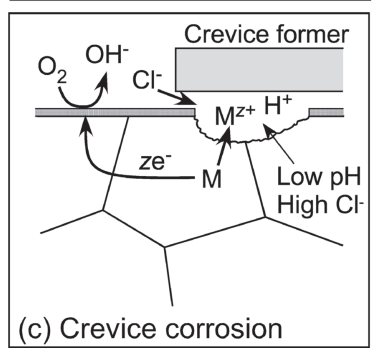

(b) Pitting corrosion
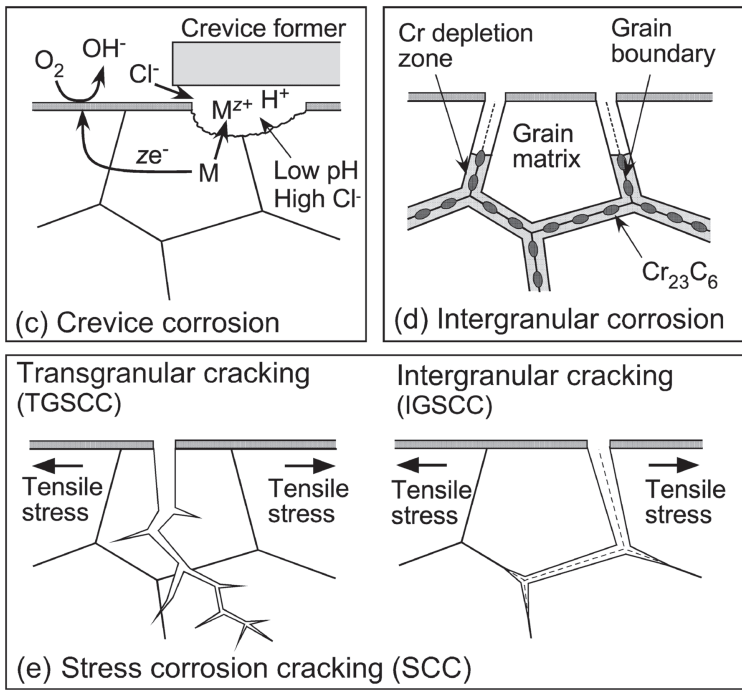

Fig. 1. Classification of corrosion of metals in aqueous environments.

この電極反応に対する平衡電位は, 反応の Gibbs エネル ギー変化 $\Delta G$ から Nernst の式で与えられる。

$$
E_{\mathrm{eq}}=-\frac{\Delta G}{z F}=E^{0}+\frac{R T}{z F} \ln \frac{a_{A}^{x} \cdot a_{B}^{y}}{a_{C}^{m} \cdot a_{D}^{n}}
$$

ここで $E^{0}$ は標準電極電位 $\left(=-\Delta G^{0} / z F\right), R$ は気体定 数, $T$ は絶対温度, $F$ は Faraday 定数である。 Nernst $の$ 式によって金属-水系の各種電気化学反応の平衡電位を 計算することができ，それを水の $\mathrm{pH}\left(=-\log a_{H^{+}}\right)$に 対してプロットすると電位-pH 図 ${ }^{2)}$ (Pourbaix 図) が得 られる。Fig. 2 に Fe- $\mathrm{H}_{2} \mathrm{O}$ 系の電位-pH 図を示す。この図 から, 溶液の酸化力 (=電位) と $\mathrm{pH}$ が変わった時の $\mathrm{Fe}$ の腐食挙動の変化を予測することができる。

電気化学反応の速度は電流密度で表される。反応が熱 活性化支配である場合の電流密度と電位の関係は, Butler-Volmer の式によって表される。

$$
i=i_{\mathrm{a}}-i_{\mathrm{c}}=i_{0}\left[\exp \left(\frac{\alpha z F \eta}{R T}\right)-\exp \left(-\frac{(1-\alpha) z F \eta}{R T}\right)\right]
$$

ここで $i_{\mathrm{a}}$ は酸化（アノード） 反応（式（1）における 左向きの反応）の速度, $i_{\mathrm{c}}$ は還元（カソード）反応の速

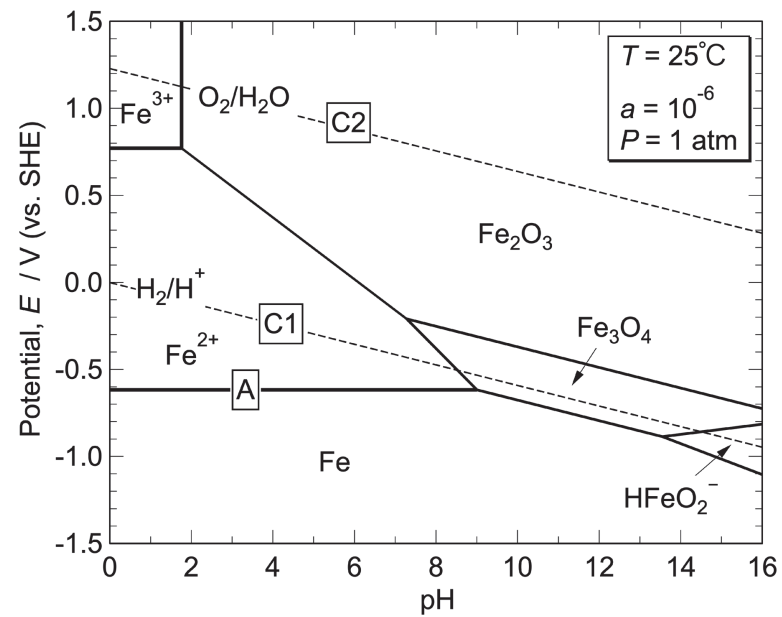

Fig. 2. Potential-pH diagram for $\mathrm{Fe}-\mathrm{H}_{2} \mathrm{O}$ system.
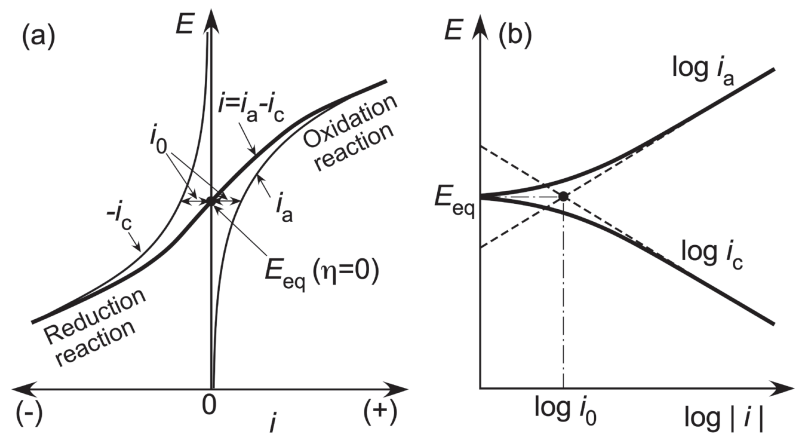

Fig. 3. Electrode kinetics as expressed by the ButlerVolmer equation, plotted on linear axes (a) and in semilogarithmic space (b).

度, $i_{0}$ は交換電流密度, $\alpha$ は対称因子, $\eta$ は過電圧であ る。過電圧 $\eta$ は式 ( 2 ） の平衡電位からの分極の大き さ $\left(\eta=E-E_{\mathrm{eq}}\right)$ を表し, 交換電流密度 $i_{0}$ は $\eta=0$, すな わち平衡電位における酸化還元反応の速度を表す。 Butler-Volmer の式を電位-電流密度平面に表示すると, Fig. 3 のようになる。電位-電流密度曲線を分極曲線と呼 ぶ。Fig. 3 (b) のように電流密度を対数表示すると, 電 位が平衡電位から十分に離れている時 $\left(|\eta| \gg R T / \alpha_{z} F\right)$ には式（3）の右辺第一項か第二項のどちらかが無視 できるので, Tafel の式と呼ばれる直線関係が成り立つ。

$$
\eta=a+b \log i
$$

酸化および還元の二つの Tafel 直線を外扦したときの交 点の電位は平衡電位, 交点の電流密度は交換電流密度と なる。

\section{3 腐食の局部電池モデル}

水溶液腐食を電気化学的に説明するために局部電池モ デルが用いられる。腐食状態にある金属表面には一次電 池の負極に相当するアノードサイトと正極に相当するカ 
ソードサイトが存在し, 両者が金属素地によって短絡さ れていると考えるモデルである。アノード抢よびカソー ドサイトが均一に分布している時には，Fig. 1 (a) のよ うに腐食は全面均一に進行する。しかし，アノードサイ トが局所に限定されている場合には，Fig. 1 (b)，（c）, （d）のような局部腐食が起こる。

塩酸や硫酸などの非酸化性の酸中に普通純度の鉄を浸 漬すると，水素の発生を伴う急速な溶解が起こる。これ はFig. 1 (a) の均一腐食の典型な例であり, 鉄が酸化 溶解するアノード反応と水素イオンが水素ガスに還元さ れるカソード反応で電池が構成されている。

$$
\begin{aligned}
& \mathrm{Fe}^{2+}+2 e^{-} \leftarrow \mathrm{Fe} \\
& E_{\mathrm{eq}, \mathrm{a}}=E_{\mathrm{a}}^{0}+\frac{R T}{2 F} \ln \frac{a_{\mathrm{Fe}^{2+}}}{a_{\mathrm{Fe}}} \\
& 2 \mathrm{H}^{+}+2 e^{-} \rightarrow \mathrm{H}_{2} \\
& E_{\mathrm{eq}, \mathrm{c}}=E_{\mathrm{c}}^{0}+\frac{R T}{2 F} \ln \frac{a_{\mathrm{H}^{+}}^{2}}{P_{\mathrm{H}_{2}}}
\end{aligned}
$$

電池反応（=腐食反応）とその起電力 $\Delta E$ は式（6）－式 (5) で与えられる。

$$
\begin{aligned}
& \mathrm{Fe}+2 \mathrm{H}^{+} \rightarrow \mathrm{Fe}^{2+}+\mathrm{H}_{2} \\
& \Delta E=E_{\text {eq, }}-E_{\text {eq, },}=E_{\mathrm{c}}^{0}-E_{\mathrm{a}}^{0}+\frac{R T}{2 F} \ln \frac{a_{\mathrm{H}^{+}}^{2}}{a_{\mathrm{Fe}^{2+}} \cdot P_{\mathrm{H}_{2}}}(7 \mathrm{~b})
\end{aligned}
$$

起電力 $\Delta E$ と電池反応の Gibbs エネルギー変化 $\Delta G$ との 間には, $\Delta G=-z F \Delta E$ の関係がある。化学反応が自発的 に進行する条件は $\Delta G<0$ であるから，一次電池が成立 するのは $\Delta E>0$ の時である。式（5b）および（6b）は， Fig. 2 の電位-pH 図中では直線 $\mathrm{A}$ および $\mathrm{C} 1$ で表され, これから酸性および中性溶液中では $\Delta E>0$ となること が分かる。このように, 鉄が水素発生を伴って腐食する のは自然なプロセスであるが, 純度 $5 \mathrm{~N}$ 以上の超高純度 鉄を塩酸や硫酸に浸漬したときには，水素がほとんど発 生せず，腐食しないように見えることがある。

このような純度による腐食挙動の違いは，電極反応の 速度を表す Butler-Volmer の式を用いて説明することが できる。横軸に電流密度の絶対值の対数 $\log |i|$, 縦軸に 電位 $E$ を取って, 式（5a）および（6a）の反応の電流電位の関係を模式的に示すと Fig. 4 のようになる。これ は Evans 図と呼ばれている。Evans 図においてアノード およびカソード反応の Tafel 直線の交点（A）が腐食電 位 $E_{\text {corr }}\left(=E_{\mathrm{c}}=E_{\mathrm{a}}\right)$ と腐食電流密度 $i_{\text {corr }}\left(=i_{\mathrm{c}}=i_{\mathrm{a}}\right)$ を与 える。カソード反応である水素発生反応の交換電流密度 $i_{0}$ が大きいと腐食速度は増加し (B 点), 逆に $i_{0}$ が小さ いと腐食速度は低下する（C 点）。 P, S , As， Sb などの 不純物を含む鉄は $i_{0}$ が大きく，腐食しやすいが，超高純 度鉄は $i_{0}$ が小さく, 腐食しにくい。また, 溶液の $\mathrm{pH}$ が

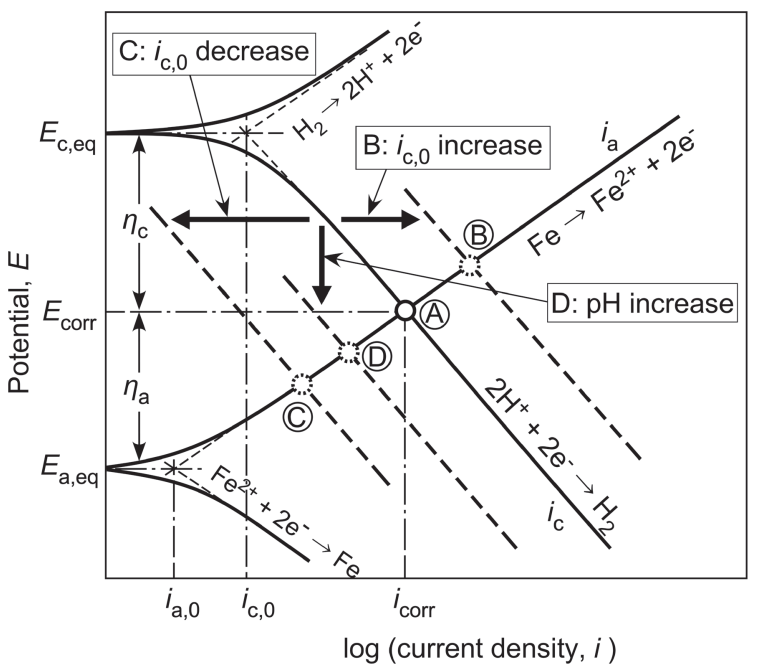

Fig. 4. Schematic Evans diagram for corroding iron in acidic solutions.

高くなると水素発生反応の平衡電位が式（6b）に従って 低下し，カソード分極曲線が低電位側にシフトするため に，腐食速度は低下する（D 点）。ただし， $\mathrm{pH}>4$ にな ると, $\mathrm{H}^{+}$濃度よりも溶存酸素濃度の方が高くなるので, 腐食のカソード反応は式（6a）の水素発生反応から, 次 式の溶存酸素の還元反応へと変化する。

$$
\mathrm{O}_{2}+4 \mathrm{H}^{+}+4 e^{-} \rightarrow 2 \mathrm{H}_{2} \mathrm{O}(\mathrm{pH}>4)
$$

Fig. 2 の電位-pH 図では直線 C2 で表されている。空気 飽和した水中の溶存酸素濃度は $8 \mathrm{ppm}\left(5 \times 10^{-4} \mathrm{~mol} / \mathrm{L}\right)$ 程度であるため, 反応速度が大きくなると電極表面の酸 素は直ちに枯渴し，溶液の沖合から表面への酸素の拡散 が反応を律速するようになる。このような拡散支配の反 応における電流密度は, Fig. 5 に示すように過電圧によ らず一定となる。そのため, 溶存酸素濃度や流速が一定 なら，腐食速度は溶液の $\mathrm{pH}$ によらず一定となるが，溶 液の流速あるいは酸素濃度を高くして表面への酸素の供 給を促進すると，腐食速度は増加する（B 点）。

以上に述べた局部電池モデルを用いると, 実際の腐食 速度に及ぼす環境および材料因子の影響を説明すること ができる。Fig. 6 は水中に打ける鉄の腐食速度と $\mathrm{pH}$ の 関係を示す3)。 $\mathrm{pH}$ が 4 以下の酸性溶液中では, $\mathrm{pH}$ の増 加によって腐食速度が急激に減少する。これは，Fig. 4 における A 点から D 点への変化に対応する。 $\mathrm{pH}$ が 4

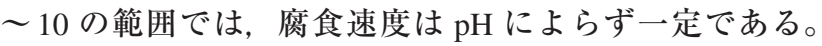
Fig. 5 に示したように，腐食のカソード反応である溶存 酸素の還元反応が拡散支配になるためである。 $\mathrm{pH}>10$ では腐食速度が再び減少に転じるが，これは後述する不 働態化によるものである。

Fig. 7 に，硫酸中に扔ける Fe-Cr 合金の腐食速度と合 


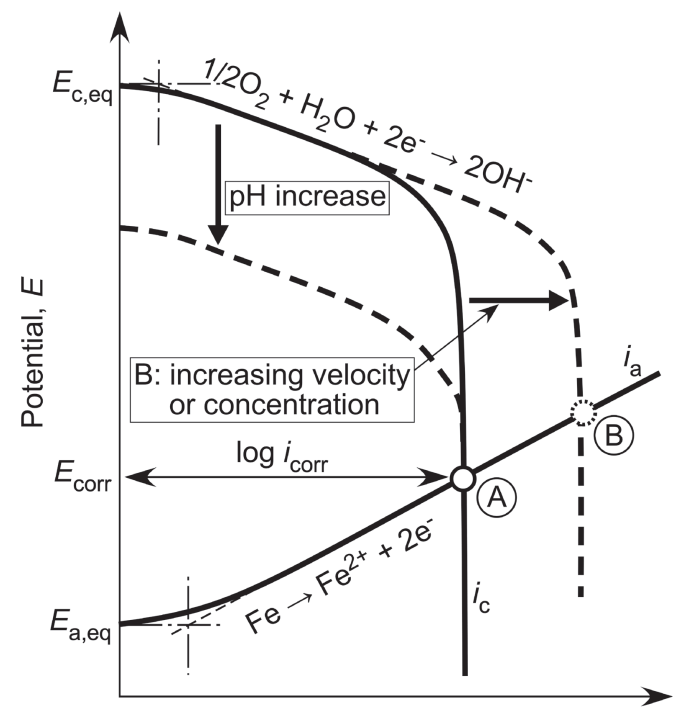

$\log$ (current density, $i$ )

Fig. 5. Evans diagram representing the corrosion of iron at a rate controlled by oxygen diffusion to the surface.

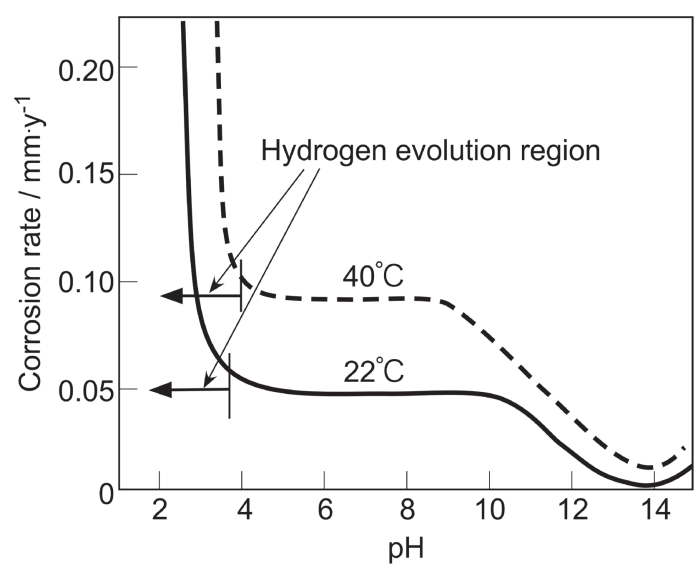

Fig. 6. Corrosion rate of iron in tap water as a function of $\mathrm{pH}$, which was adjusted by adding $\mathrm{HCl}$ or $\mathrm{NaOH}$.

金の $\mathrm{Cr}$ 含有量の関係を示す4)。ここで, 高純度 $\mathrm{Fe}-\mathrm{Cr}$ 合 金は，陰イオン交換法と浮遊带溶融法を組合せた精製法 によって作製した純度 99.999 at\% 以上の超高純度鉄と 市販の高純度 Cr（公称純度 99.99 mass\%）を用いてアル ゴンアーク溶解により作製したものである。ここで at $\%$ は元素比 (モル比)，mass\% は質量比を表す。電解金属 （純度 99〜99.9 mass\%）を真空高周波誘導溶解した合金 および市販のフェライト系ステンレス鋼と比べると, 高 純度合金の腐食速度は非常に低い。30\% Cr で比較する と約 1/100 である。水素発生が抑制されるためであり, Fig. 4 に扔ける A 点から C 点への変化に相当する。な お, $\mathrm{Cr}$ 含有量の増加によって腐食速度が増加するのは, 後に Fig. 9 で示すように $\mathrm{Cr}$ の活性溶解が $\mathrm{Fe}$ よりも低い 電位で起こるためである。Fig. 7 から，フェライト系に

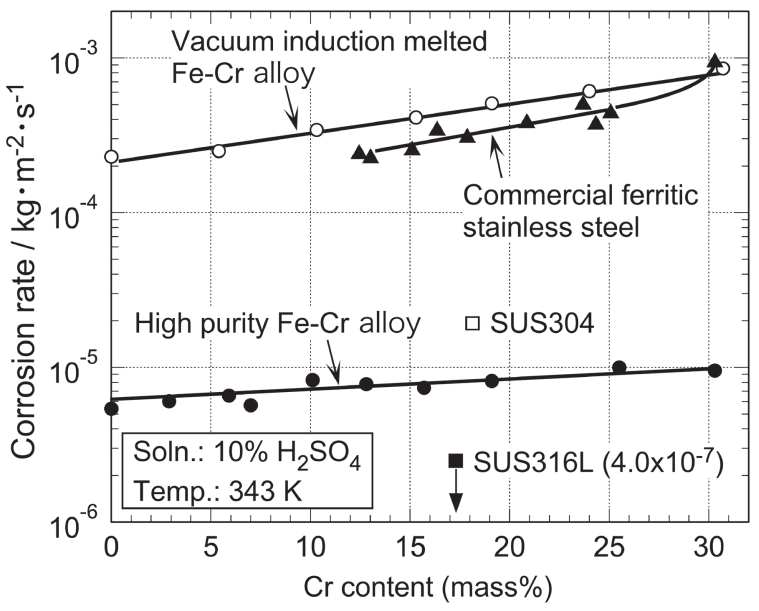

Fig. 7. Corrosion rate of $\mathrm{Fe}-\mathrm{Cr}$ alloys in $10 \% \mathrm{H}_{2} \mathrm{SO}_{4}$ as a function of $\mathrm{Cr}$ content of the alloy.

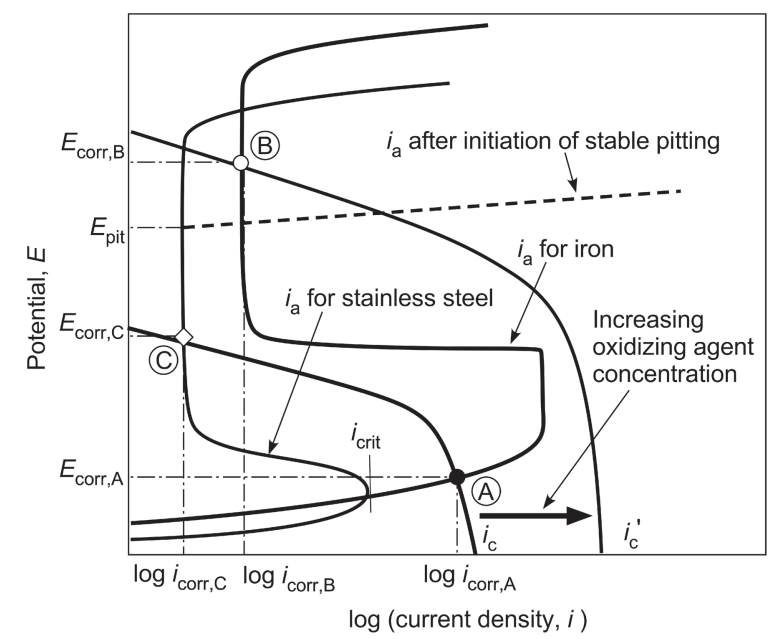

Fig. 8. Evans diagram representing the passivation of iron by immersing in a strong oxidizing solution or by alloying $\mathrm{Cr}$. $i_{\text {crit }}$ : critical passivation current density, $E_{\text {pit }}$ : pitting potential.

比ベてオーステナイト系の SUS304 鋼の腐食速度は約 1 桁低く, SUS316L 鋼はさらに 1 桁以上低いことが分か る。活性溶解が Ni およびMo 添加によって抑制される ことを示している。活性溶解域の低電位側では $\mathrm{Ni}$ は金 属状態が安定, Mo は酸化物が安定であるため, 溶解抑 制作用を示すと考えられる。

\section{4 不働態化と不働態皮膜}

耐食材料の優れた防食機能は不働態化によるものであ ることが多い。Fig. 8 に不働態化現象を示す金属の Evans 図を模式的に示す。鉄を硫酸酸性溶液中でアノー ド分極すると，電流密度は Butler-Volmer の式に従って 増加するが，やがてほぼ一定となり，その後，数 $\mu \mathrm{A} /$ $\mathrm{cm}^{2}$ まで急激に減少して不働態化する (Fig.9 参照)。鉄 は希硝酸中では不働態化しないが, 濃硝酸中では不働態 化する。希硝酸中で不働態化しないのはカソード反応で 


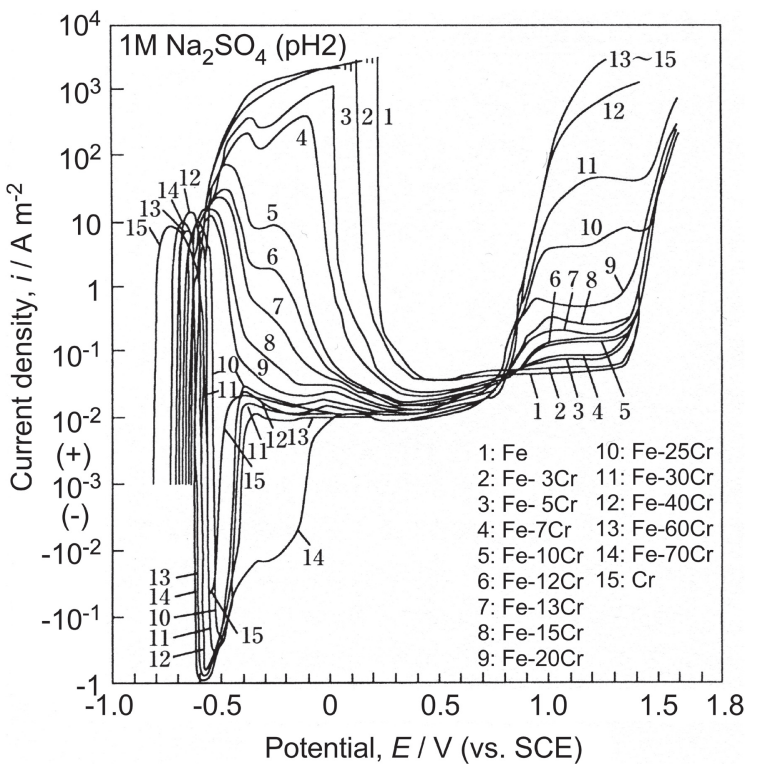

Fig. 9. Anodic polarization curves of a series of $\mathrm{Fe}-\mathrm{Cr}$ alloys in $\mathrm{pH} 2.0,1 \mathrm{M} \mathrm{Na}_{2} \mathrm{SO}_{4}(298 \mathrm{~K})$.

ある硝酸の還元反応の電流密度が小さく, そのためアノ ードおよびカソード分極曲線の交点が活性溶解域内（A 点）にとどまるからである。硝酸濃度が高くなり，その 還元電流密度がアノード溶解のピーク電流密度を超える と, 二つの分極曲線の交点は不働態域内（B 点）に入る ので，自発的な不働態化が起こる。鉄に $10.5 \%$ 以上のク ロムを添加した合金であるステンレス鋼は, 鉄に比べる とアノード溶解のピーク電流密度 (臨界不働態化電流密 度 $i_{\text {crit }}$ と呼ばれる）が何桁も低いので, 希硝酸中でも容 易に不働態化する (C 点)。Fig. 9 に Cr 含有量の異なる 一連の Fe-Cr 合金のアノード分極曲線を示す5)。Cr 含有 量が 5〜20\%の合金では活性帯域に二つの電流ピークが 現れ, Cr 含有量を増すと, 高電位側の第二電流ピークが 著しく低くなることが分かる。 $\mathrm{Cr}$ の効果は活性溶解域の 高電位側（不働態域の低電位側）で特に顕著に現れる。

ステンレス鋼の耐食性を担う不働態皮膜については, 厚さ，化学組成，電子的性質，イオン輸送特性などの諸 性状が調べられている ${ }^{6 \sim 8)}$ 。Fig. 10 に，Fe-Cr 合金の不 働態皮膜の $\mathrm{Cr}^{3+}$ カチオン分率 $X_{\mathrm{Cr}}$ と合金の $\mathrm{Cr}$ 含有量の 関係を示す5)。合金の $\mathrm{Cr}$ 含有量を増すと共に $X_{\mathrm{Cr}}$ は急激 に増加して, ステンレス鋼の最少 $\mathrm{Cr}$ 含有量である $10.5 \%$ を超えると $X_{\mathrm{Cr}}>0.5$ となり， $30 \%$ では $X_{\mathrm{Cr}}>0.7$ となることが分かる。

孔食やすき間腐食などの局部腐食が発生する時，不働 態が局部的に破壊される場所の液性は, Fig. 1 (b)，(c) 中に模式的に示したように低 $\mathrm{pH}$, 高 $\mathrm{Cl}^{-}$濃度になってい る。したがって, 不働態皮膜の防食特性を理解するため には, $\mathrm{HCl}$ のような酸性塩化物溶液中における皮膜の溶

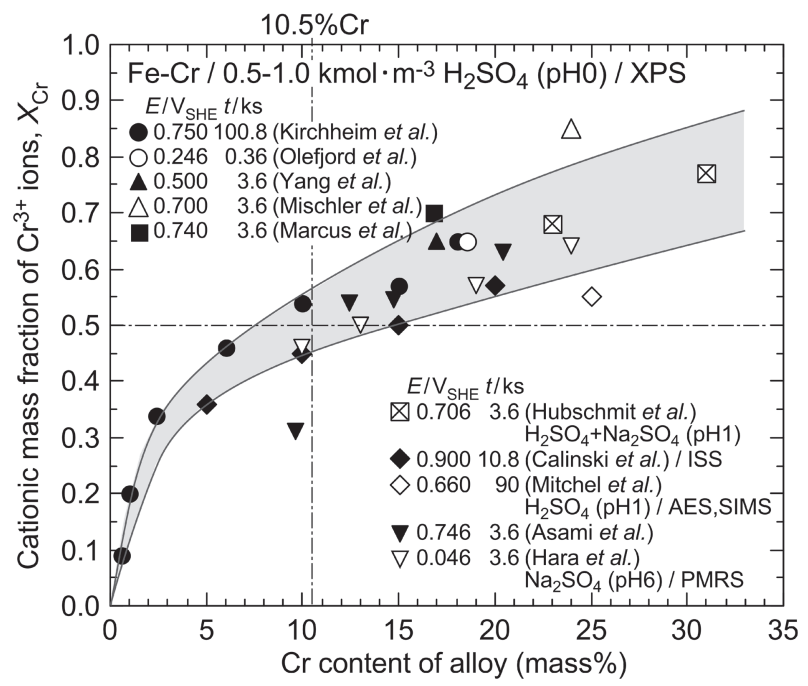

Fig. 10. Cationic mass fraction of $\mathrm{Cr}^{3+}$ ions in passive films on $\mathrm{Fe}-\mathrm{Cr}$ alloys a function of $\mathrm{Cr}$ content of the alloys.

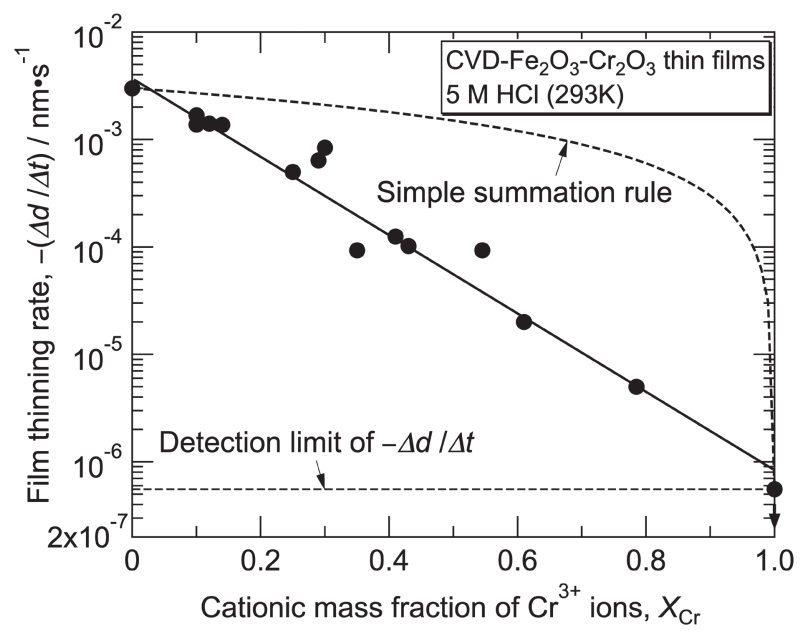

Fig. 11. Film thinning rate of $\mathrm{CVD}-\mathrm{Fe}_{2} \mathrm{O}_{3}-\mathrm{Cr}_{2} \mathrm{O}_{3}$ composite films in $5 \mathrm{M} \mathrm{HCl}$ as a function of cationic mass fraction of $\mathrm{Cr}^{3+}$ ions in the films.

解速度を知ることが必要である。しかし, 多くの汎用ス テンレス鋼は $\mathrm{HCl}$ 中では不働態化しないため, そのよう な評価は困難である。そこで, 著者らは気相析出法で作 製した $\mathrm{Fe}_{2} \mathrm{O}_{3}-\mathrm{Cr}_{2} \mathrm{O}_{3}-\mathrm{NiO}$ 系人工不働態皮膜を用いて, $\mathrm{HCl}$ 中における溶解速度に及ぼす合金元素の影響を調べた ${ }^{8,99}$ 。

Fig. 11 に, $5 \mathrm{M} \mathrm{HCl}$ 中の $\mathrm{Fe}_{2} \mathrm{O}_{3}-\mathrm{Cr}_{2} \mathrm{O}_{3}$ 薄膜の膜厚減少 速度 (以下, 溶解速度とする) と薄膜の $\mathrm{Cr}^{3+}$ カチオン分 率 $X_{\mathrm{Cr}}$ の関係を示す ${ }^{10)}$ 。溶解速度は $X_{\mathrm{Cr}}$ に対して指数関 数的に減少し, $X_{\mathrm{Cr}}=0.5(10.5 \% \mathrm{Cr}$ 鋼の実不働態皮膜に 相当）では約 $1 / 100$ まで低下する。 $X_{\mathrm{Cr}}=0.5$ の皮膜の溶 解速度 $\left(5 \times 10^{-5} \mathrm{~nm} / \mathrm{s}\right)$ は, この皮膜 $1 \mathrm{~nm}$ を $5 \mathrm{M} \mathrm{HCl}$ 中で全て溶解するのに約 5.5 時間必要であることを意味 しており， $\mathrm{Cr}$ 濃縮した複合酸化物は $\mathrm{HCl}$ に対する耐食 性が極めて高いことが分かる。 


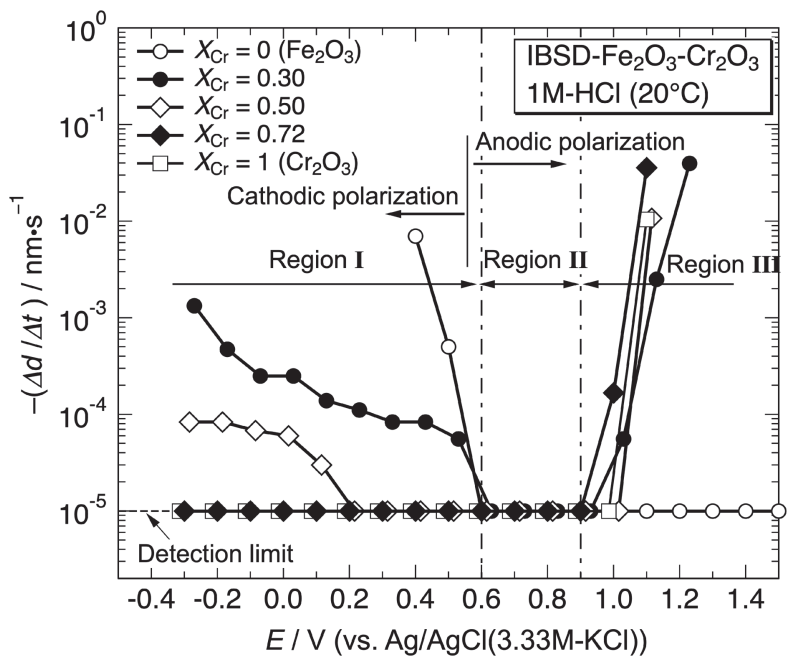

Fig. 12. Film thinning rate of IBSD- $\mathrm{Fe}_{2} \mathrm{O}_{3}-\mathrm{Cr}_{2} \mathrm{O}_{3}$ composite films in $1 \mathrm{M} \mathrm{HCl}$ as a function of potential.

Fig. 12 に示すように $\mathrm{Fe}_{2} \mathrm{O}_{3}-\mathrm{Cr}_{2} \mathrm{O}_{3}$ 薄膜の溶解速度は電 位に依存する ${ }^{11)}$ 。不働態域の低電位側（領域 I）では $\mathrm{Fe}_{2} \mathrm{O}_{3}$ 成分が還元溶解し, その速度は電位が低いほど, すなわち $\mathrm{Fe}-\mathrm{Cr}$ 合金の活性溶解域に近づくほど大きくな るが， $X_{\mathrm{Cr}}$ を増すと低下し， $X_{\mathrm{Cr}}>0.7(30 \mathrm{Cr}$ 鋼相当）で 検出限界以下になった。 $\mathrm{Cr}$ 濃縮した不働態皮膜の防食 機能は不働態域の低電位側において顕著に発現する。

\section{5 不働態の破壊と局部腐食}

ステンレス鋼を実用する上で問題となる腐食トラブル の大半は孔食などの局部腐食である。ステンレス鋼の孔 食は，ハロゲン化物イオン $\left(\mathrm{Cl}^{-}, \mathrm{Br}^{-}, 1^{-}\right.$など $)$を含 む環境中で不働態が局所的に破壊されることで発生する。 Fig. 8 中に破線で示したように, 孔食の発生はアノード 分極曲線における不働態状態からの急激な電流上昇によ って検知され，この電流上昇が始まる電位が孔食電位 $E_{\mathrm{pit}}$ であり，耐孔食性を表す代表的特性值である。孔 食の防止に有効な元素は $\mathrm{Cr}, \mathrm{Mo}, \mathrm{N}$ であり，これらの 元素の濃度で決まる耐孔食性指標 (pitting resistance equivalent, PRE）が用いられている。

$$
\mathrm{PRE}=[\% \mathrm{Cr}]+\alpha[\% \mathrm{Mo}]+\beta[\% \mathrm{~N}]
$$

ここで $\alpha=3 \sim 3.3, \beta=10 \sim 30$ である。Fig. 13 に $3.5 \% \mathrm{NaCl}\left(80^{\circ} \mathrm{C}\right)$ 中におけるステンレス鋼の $E_{\mathrm{pit}}$ と $\mathrm{PRE}(=[\% \mathrm{Cr}]+3[\% \mathrm{Mo}])$ の関係を示す ${ }^{12)}$ 。 $E_{\mathrm{pit}}$ は PRE の増加と共に増加しており，孔食発生の抑制には $\mathrm{Cr}$ と Mo の添加が有効であることが分かる。また, Ni を含む オーステナイトステンレス鋼はフェライトステンレス鋼 に比べて耐孔食性に優れている。Fig. 11 から推察され るように不働態皮膜の耐酸性が向上することに加えて, 局部的な酸性, 高濃度塩化物環境での合金素地の活性溶

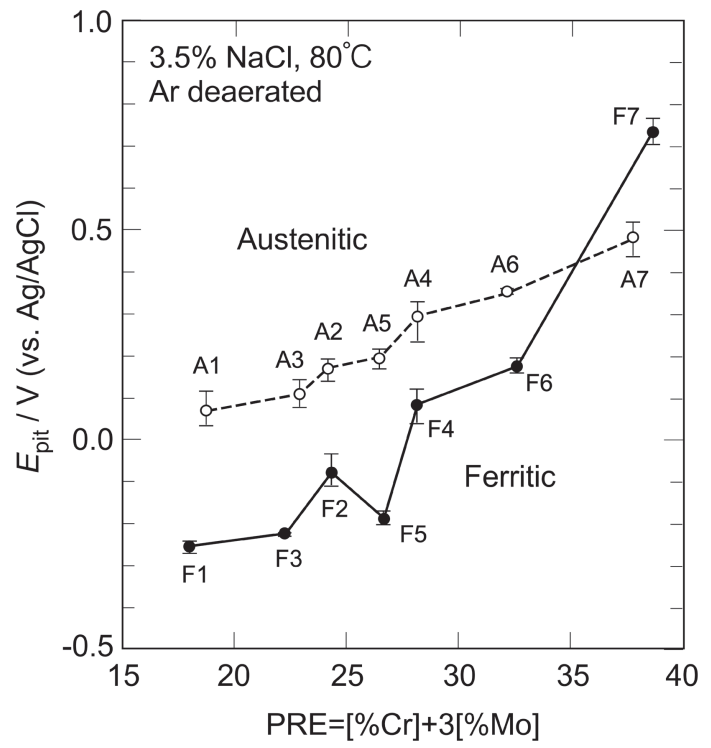

Fig. 13. Pitting potential of ferritic and austenitic stainless steels in $3.5 \% \mathrm{NaCl}\left(80^{\circ} \mathrm{C}\right)$ as a function of pitting resistance equivalent, PRE.

解が抑制されることで，脱不働態化しにくく，かつ再不 働態化しやすくなるためであると考えられる。N の効果 に関しては不働態皮膜の改質と活性溶解の抑制効果が考 えられるが，定説は未だない。

\section{3. 局部腐食研究の最近の進歩}

\section{1 PRE との相関性を示さない理想ステンレス鋼}

Fig. 14 に, Fe-Cr 二元合金と SUS 304 鋼のバルク材と イオンビームスパッタ薄膜の $E_{\mathrm{pit}}$ と PRE の関係を示す9)。 図中には SUS 304 鋼のスパッ夕薄膜, SUS 304 および SUS 316L 鋼の市販材と高純度材のデー夕も合わせて示

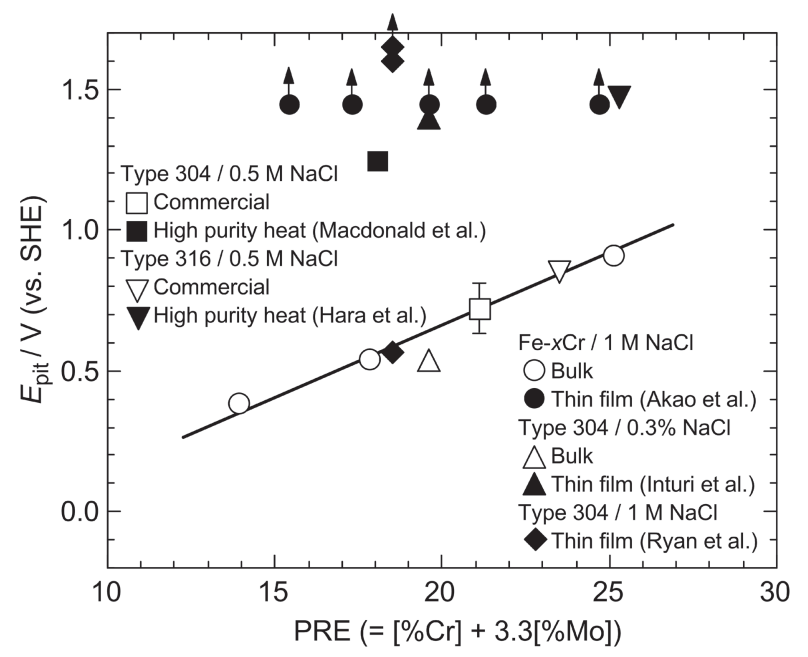

Fig. 14. Pitting potential vs. PRE relationships for thin film $\mathrm{Fe}-\mathrm{Cr}$ alloys and high purity stainless steels as compared to bulk alloys and commercial steels. 

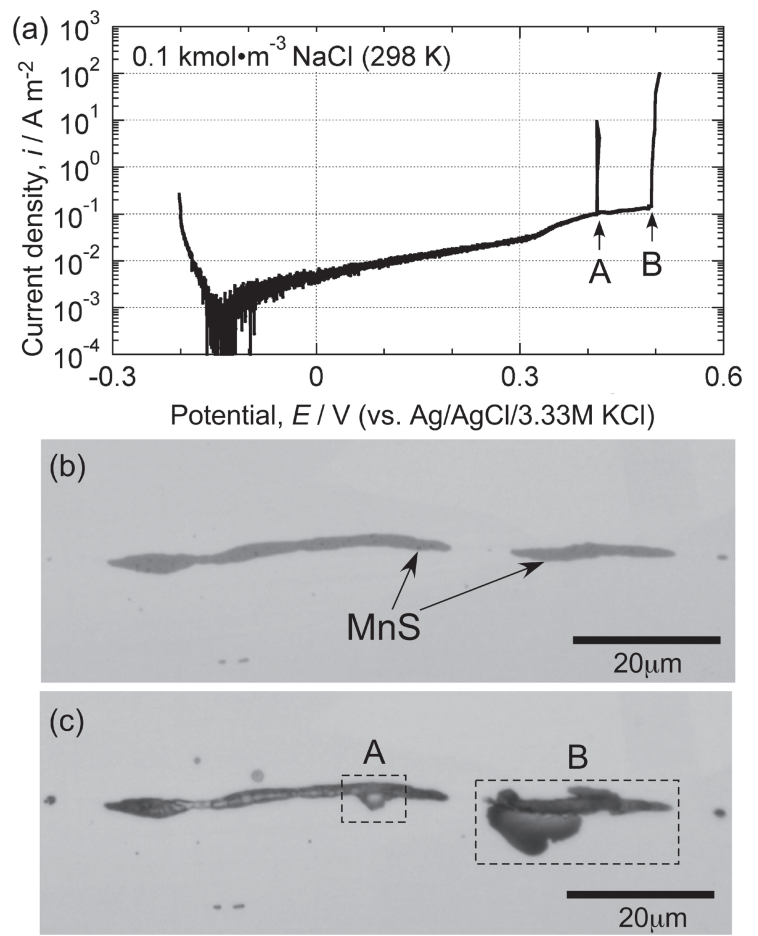

Fig. 15. Microscopic polarization curve of SUS 304 stainless steel (electrode area of $5.0 \times 10^{-8} \mathrm{~m}^{-2}$ ) in $0.1 \mathrm{M} \mathrm{NaCl}$ (a). Optical microscopy images of $\mathrm{MnS}$ inclusions in the electrode area before and after the polarization, (b) and (c).

してある。ここでスパッタ薄膜と高純度鋼は，光学顕微 鏡で検出されるようなミクロスケールの介在物等を含ん でおらず，一種の理想ステンレス鋼であると見なすこと ができる。Fig. 14 に扔いて，バルクの Fe-Cr 合金，市販 の SUS 304 および SUS 316L 鋼の $E_{\mathrm{pit}}$ と PRE との間には Fig. 13 と同様の直線関係が認められる。しかし，スパ ッ夕薄膜と高純度鋼はこの直線関係には従わず，PRE $=15$ 程度でも孔食は発生しない。

\section{2 硫化物介在物起点の孔食発生機構}

マイクロ電気化学計測法を用いた最近の研究によっ $\tau^{13,14)}, \mathrm{MnS}$ 系介在物を起点とする孔食発生過程が解析 された。Fig. 15 (a) に動電位アノード分極曲線を, Fig. 15 (b)，(c) に実験前後の電極面の光学顕微鏡写真 を示す ${ }^{15)}$ 。電極面積は約 $150 \mu \mathrm{m} \times$ 約 $300 \mu \mathrm{m}$ である。 $0.3 \mathrm{~V}$ 付近から $\mathrm{MnS}$ のアノード溶解による電流上昇が起 こり, $0.41 \mathrm{~V}$ で再不働態化性ピットの発生による電流入 パイク（A）が現れ，0.51 V で成長性ピットの発生によ る電流の急上昇（B）が現れた。再不働態化性ピットは $\mathrm{MnS}$ と鋼素地の界面に発生している。成長性ピットの 発生位置は測定終了後の写真では特定できないが，分極 測定中に記録したビデオ画像より, 再不働態化性ピット と同様に $\mathrm{MnS} /$ 鋼界面から発生することがわかった。 実験終了後の試料を FIB で加工し，表面と断面の
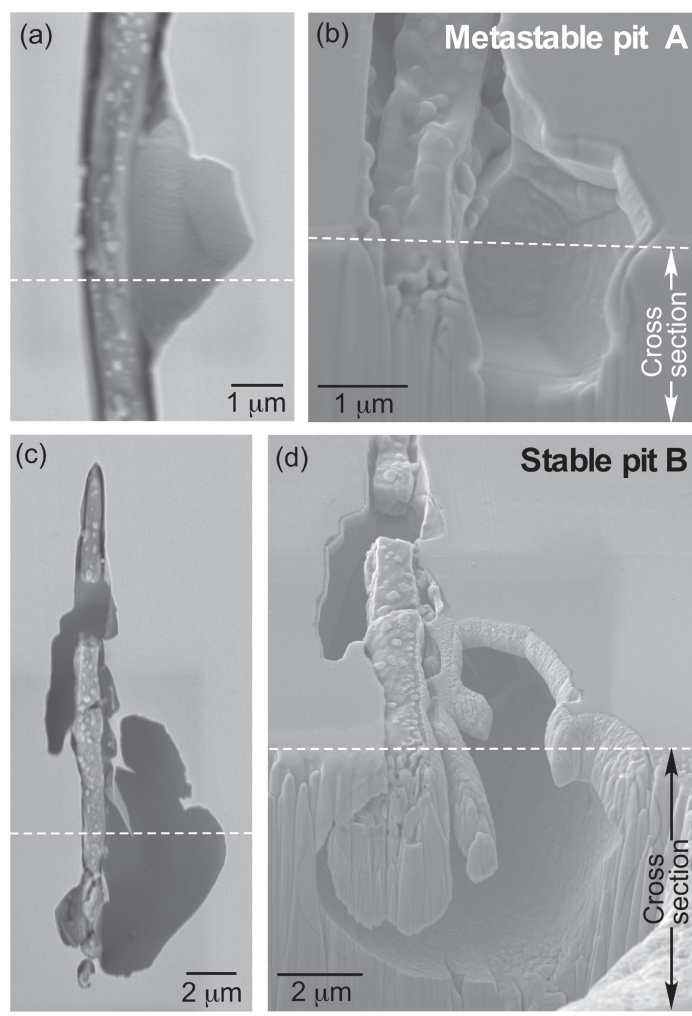

Fig. 16. SEM images of the metastable pit $(a, b)$ and the stable pit (c, d) after the polarization measurement shown in Fig. 15(a). The bottom half of the images show the FIB cross-section.

SEM 観察を行った結果を Fig. 16 に示す ${ }^{15)}$ 。再不働態化 性ピットは口径と媣さが同程度で浅いのに対して, 成長 性ピットは試料内部まで媣く溶解が進展している。ま た, $\mathrm{MnS}$ と鋼の界面に溝が形成されていることが注目 される。In-situ 顕微ラマン分光法による分析の結果, $\mathrm{MnS} /$ 境界部の溝の所には元素状硫黄（S）が存在するこ とが分かった ${ }^{16)}$ 。の元素状 $\mathrm{S}$ は $\mathrm{MnS}$ のアノード溶解 生成物である $\mathrm{S}_{2} \mathrm{O}_{3}{ }^{2-}$ イオンから不均化反応によって生じ るものと考えられる。元素状 $\mathrm{S}$ を含む $\mathrm{NaCl}$ 溶液中でア ノード分極曲線を測定した結果，元素状 S が存在する と, $\mathrm{Cl}^{-}$イオンとの相乗作用によって $\mathrm{pH} 3.5$ 程度の溶液 であっても SUS 304 鋼は活性溶解し, 不働態化しない ことが分かった ${ }^{16)}$

これらの結果に基づき, Fig. 17 に示すような孔食発生 機構が提案された ${ }^{16)}$ 。 MnS のアノード溶解生成物である $\mathrm{S}_{2} \mathrm{O}_{3}{ }^{2-}$ イオンから不均化反応によって元素状の $\mathrm{S}$ が生 じ，これと $\mathrm{Cl}^{-}$イオンの相乗作用によって $\mathrm{MnS} /$ 鋼界面 のステンレス鋼の溝状溶解が進行し, 溝内部での局所溶 解によってピットが発生する。この機構により, Fig. 13 のような孔食電位の PRE 依存性は, 脱不働態化の起点 となる弱点（MnS など）を含む鋼で成立するものであり， Fig. 14 に示す理想ステンレス鋼では成立しないことが説 


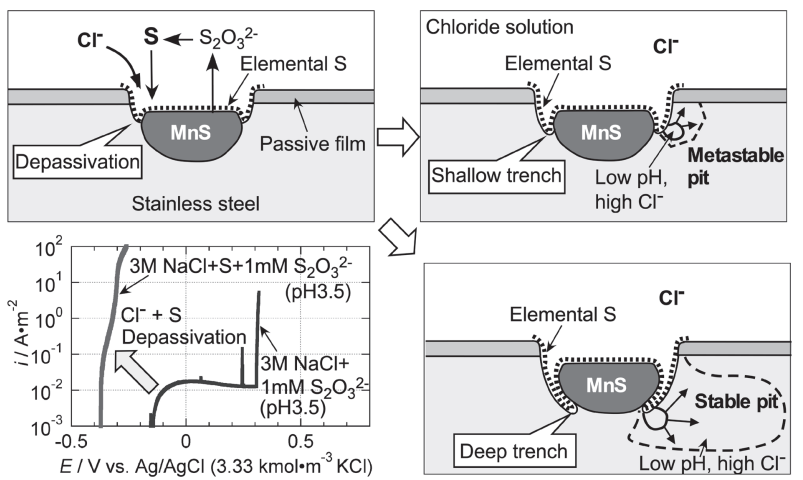

Fig. 17. Schematic of the pit initiation mechanism at $\mathrm{MnS}$ inclusion in stainless steel.

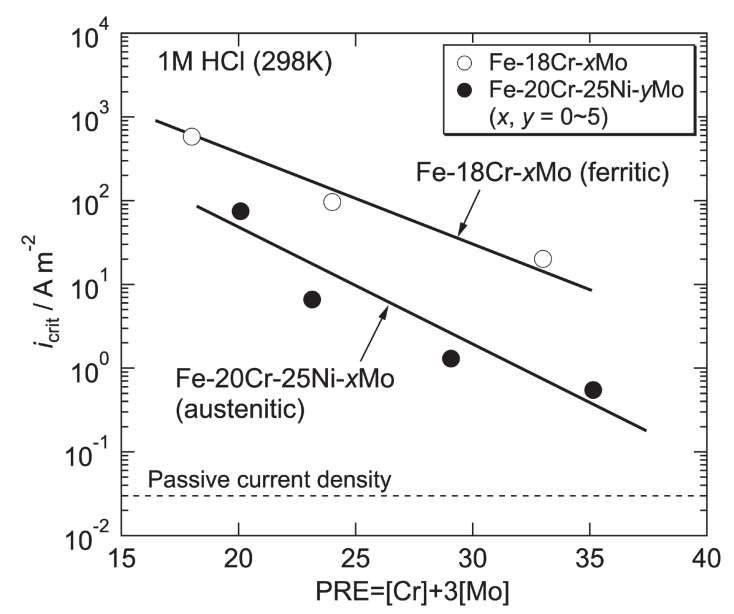

Fig. 18. Critical passivation current density, $i_{\text {crit }}, v s$. pitting resistance equivalent, PRE, for $\mathrm{Fe}-18 \mathrm{Cr}$-xMo and Fe-20Cr25Ni-yMo alloys in $1 \mathrm{M} \mathrm{HCl}$.

明できる。ピット発生過程が不働態皮膜の破壊とそれに 続く鋼の溝状溶解から成ることを考慮すると, 孔食電位 に及ぼす $\mathrm{Cr}$ や Mo の効果は, 溝内部での鋼のアノード 溶解，すなわち強酸性の高濃度塩化物環境での鋼の活性 溶解の抑制により発現すると考えることができる。再不 働態化しやすく，脱不働態化し難くなると考えても良 (17)。1 M HCl 中に扔けるフェライト系 $\mathrm{Fe}-18 \mathrm{Cr}-x \mathrm{Mo}$ 合 金とオーステナイト系 Fe-20Cr-25Ni-yMo 合金のアノー ド分極曲線 $18,{ }^{199}$ から臨界不働態化電流密度 $i_{\text {crit }}$ を求め, PRE（=[Cr] $+3[\mathrm{Mo}] ）$ に対してプロットした結果を Fig. 18 に示す。いずれの合金の $i_{\text {crit }}$ も PRE との相関性を 示し，また Ni を含むオーステナイト系合金の方が $i_{\text {crit }}$ は 低い。これは $\mathrm{Ni}$ 含有鋼の $E_{\mathrm{pit}}$ が高いこと（Fig. 13）に対 応しており, 活性溶解抑制, 不働態化促進作用を有する 元素が孔食の抑制にも有効であることを示唆している。

\section{4. まと め}

金属材料の腐食挙動を理解するためには電気化学的な 基碟的知識に加えて, 材料のミクロ組織やミクロ構造の 影響を知ることが重要であることを示した。ミクロ組織 ・構造に着目した研究のイノベーションが新規の耐食材 料および表面改質法の開発に繋がると考えられる。国連 の SDGs が目指しているような持続可能な社会の実現の ためには，省資源化と環境負荷低減が重要であることか ら，著者らは未来型ステンレス鋼の一つを「耐食性を極 限まで高めた低 $\mathrm{Cr}$ 鋼」であると考え，それを「グリー ンステンレス鋼」と名付けた ${ }^{8}$ 。今後の基礎的な研究の 発展が次世代ステンレス鋼の開発に結実することを期待 している。

\section{文献}

1) 原 信義 : 真空 44, 860 (2001).

2) M. Pourbaix : "Atlas of Electrochemical Equilibria in Aqueous Solutions” (NACE, Houston, 1996) p. 307.

3) N.D. Tomashov: "Theoretical Corrosion and Protection of Metals" (The MacMillan Company, New York, 1966) p. 296

4) 杉本克久, 原 信義, 一色 実, 江島辰彦, 井坦謙三 : 日本金属学会誌 46, 703 (1982).

5) 原 信義, 杉本克久 : “金属データブック改訂 4 版” (丸善, 2004) p. 38.

6) 杉本克久 : 鉄と鋼 70,637 (1984).

7) 杉本克久 : 材料と環境 57, 375 (2008).

8) 原 信義: 材料と環境 59, 212 (2010).

9）原 信義：まてりあ 55, 207 (2016).

10) K. Sugimoto, M. Seto, S. Tanaka and N. Hara : J. Electrochem. Soc. 140, 1586 (1993).

11) K. Sugimoto, M. Son, N. Akao and N. Hara : "Pits and Pores II", (The Electrochemical Society, ECS Proc. Vol. 2000-25), p. 155.

12) T. Ujiro, K. Yoshioka and R.W. Staehle : Corrosion 50, 953 (1994).

13）原 信義：材料と環境 63,132 (2014).

14）千葉 亜耶, 武藤 泉, 菅原 優, 原 信義：表面科 学 36, 18 (2015).

15) A. Chiba, I. Muto, Y. Sugawara and N. Hara : J. Electrochem. Soc. 159, C341 (2012).

16) A. Chiba, I. Muto, Y. Sugawara and N. Hara : J. Electrochem. Soc. 160, C511 (2013).

17) M. Nishimoto, I. Muto, Y. Sugawara and N. Hara : J. Electrochem. Soc. 166, C3081 (2019).

18) K. Sugimoto and Y. Sawada : Corros. Sci. 17, 425 (1977).

19) M. Son, N. Akao, N. Hara and K. Sugimoto : J. Electrochem. Soc. 148, B43 (2001). 